\title{
Blended Learning Model During the Covid-19 Pandemic: Analysis of Student's' Mathematical Disposition
}

\author{
Ahmad Fadillah', Dian Nopitasari'2, Barra P. Pradja ${ }^{3}$ \\ ${ }^{123}$ Mathematics Education Departement, Universitas Muhammadiyah Tangerang, Indonesia \\ 1fadielalgebra4@gmail.com, ㄹdian.nopitasari511@gmail.com, 33barrapradja@gmail.com
}

\begin{tabular}{|c|c|}
\hline & ABSTRACT \\
\hline Article History: & \multirow{12}{*}{$\begin{array}{l}\text { The purpose of this study is to describe the mathematical disposition of students } \\
\text { who use blended learning during the Covid-19 pandemic. This research is a } \\
\text { descriptive qualitative research. The research subjects were four students from } \\
\text { the sixth semester of mathematics education study program. The research } \\
\text { instrument was a student mathematical disposition questionnaire. The results of } \\
\text { the study concluded that the average level of mathematical disposition of students } \\
\text { was classified as moderate. If seen from the indicators, only the monitor and } \\
\text { evaluate indicators are classified as high category. Indicators of persistence and } \\
\text { perseverance, especially when lecturers present interesting contextual problems. } \\
\text { Many indicators of curiosity arise when lecturers invite students to be active in } \\
\text { learning, for example students are invited to study in groups. Many self-confidence } \\
\text { indicators appear when lecturers ask students questions. While many flexible } \\
\text { indicators appear when lecturers give open ended questions. }\end{array}$} \\
\hline Received : 08-07-2020 & \\
\hline Revised $1: 15-07-2020$ & \\
\hline Revised $2: 12-09-2020$ & \\
\hline Accepted : 14-09-2020 & \\
\hline Online $\quad: 03-10-2020$ & \\
\hline \multirow{5}{*}{$\begin{array}{l}\text { Keyword: } \\
\text { Blended learning; } \\
\text { Edmodo software; } \\
\text { COVID-19 pandemic; } \\
\text { Mathematical } \\
\text { disposition. }\end{array}$} & \\
\hline & \\
\hline & \\
\hline & \\
\hline & \\
\hline & \\
\hline \multicolumn{2}{|c|}{ dol Crossref } \\
\hline https://doi.org/10.317 & This is an open access article under the CC-BY-SA license \\
\hline
\end{tabular}

\section{A. INTRODUCTION}

Since Covid-19 entered Indonesia in mid-March, various schools, campuses, and educational institutions have implemented online learning policies to ensure the continuity of their teaching and learning process. The existence of the Covid-19 pandemic is forcing us to move faster in terms of learning innovation, especially technology-based learning. Technology that continues to develop along with the increasing age and human needs, of course, increasingly demanding people to be more creative in creating more sophisticated technologies. The progress of science and technology today, is inseparable from the role of mathematics as a basic science. Mathematics also has strategic values in developing ways of thinking logically, being critical, creative and innovative as well as being able to be applied in various problems both related to students' daily lives and with other knowledge.

Research exclusively focusing on global pandemics and digital learning Covid-19 is on the rise in 2020. Some researchers have conducted studies on the knowledge needed for the adoption of digital technology during the Covid-19 crisis. For example, Agnoletto \& Queiroz 
(2020) in their paper Covid-19 and challenges in Education, they argue that digital logic is not simple but there are ongoing protests to launch emergency action tools, mostly, adopting the use of digital technology for learning. While a study by Roy (2020) in Australia, presents some tips that can help children learn from home during the Covid-19 period. In one of the tips, he suggested that teachers need to download several teleconferencing facilities (e.g. Skype, Zoom, Lifesize) that can be used to deliver lessons remotely (Mulenga \& Marbán, 2020).

The existence of the Covid-19 pandemic has made all learning activities in Indonesia that used to be face-to-face learning turned into online learning. Baytiyeh (2019), believes that maintaining learning and communication during school closure by all possible means is important (Mulenga \& Marbán, 2020). In support of this claim Burke (2020), strongly points out that in an effort to reshape education, there are certain steps that need to be implemented during the Covid-19 school closure period. These steps include; maintain communication with students, parents, teachers and other staff members through email and telephone calls, maintain access to learning materials such as Google Apps (e.g. Google Drive, Dropbox, cloud) for education, Moodle Cloud, Edmodo, or social media tools (for example, WhatsApp, Twitter, YouTube, Facebook, Instagram, Yahoo) and maintain access to data through cloud computing for servers and backup in locations other than school (Dempsey \& Burke, 2020). An innovative learning model that is able to combine traditional learning activities with online learning is called the blended learning model. So for one semester, learning in Indonesia applies the blended learning model, namely in February - March with face-to-face learning, and March - May with online learning. According to Watson \& Murin (2014), Blended learning is a formal education program in which a student receives a portion of learning through online learning that controls the time, place, choice of material, speed of learning in the hands of students and part of the learning is guided learning outside home, and the learning modalities of these students are interconnected so that students get an integrated learning experience.

Blended learning is not new in the world of Education. In various places around the world Blended Learning programs have been carried out in schools with various models. According to Michael B. Horn and Heather Staker (2014) in his book Blended: Using Disruptive Innovation to Improve Schools the implementation of Blended Learning in various places in the world can be divided into four models, namely: (1) Rotation Model, in Rotation Model of learning conducted by students rotating between learning modalities, one of which is online learning within a certain schedule or based on teacher instructions; (2) Flex Model, in Flex model students hold full control in their learning. Students move from one learning modality to another learning modality in flexible schedules tailored to each individual. Facilitation of instructors face to face is done as far as necessary, such assistance can be in the form of teaching in small groups, group projects, or personal guidance; (3) A La Carte Model, in this model students follow a fully online learning and also face-to-face learning at the learning center or school. Learning assistance not only occurs when face to face, but also when learning online; and (4) Remote model or enriched Virtual, in this model students do face-toface learning at school and online learning at home (outside of school). Face-to-face learning takes place in accordance with the wishes of students (usually very rare) and online learning is carried out to complete learning to complete face-to-face meetings (Horn \& Staker, 2014). 
Castro (2019) sees blended learning as a method that creates a learning environment suitable for students in tertiary institutions. Blended learning can be seen as a combination of learning that combines web-based communication, video, audio, synchronous, and asynchronous with face-to-face learning (Quevedo, 2011). Eryilmaz (2015) research results show that in blended learning, students can learn more effectively in an integrated learning environment.

The conceptualization of digital classrooms from blended learning emphasizes the use of online technology in the classroom. Blended learning is generally used to describe the use of digital technology in the classroom. Many such studies are carried out in K-12 settings (for example, Çakır \& Bichelmeyer, 2016; Hong, Hwang, Tai, \& Kuo, 2016; Smith \& Suzuki, 2015) although there are also such papers from higher education settings (for example, Jou, Lin, \& Wu, 2016; Van Niekerk \& Webb, 2016). An example is a study in which students access multimedia lessons using tablet computers and earphones that they receive when entering class (Smith \& Suzuki, 2015). Other studies evaluate curricula with online and hardcopy material developed for use in schools (Çakır \& Bichelmeyer, 2016).

The application of the blended learning model requires the help of computer-based media (online) that can support online learning activities. The media used in this study was Edmodo. Edmodo is a social media network designed by Jeff O'Hara and Nick Borg in 2008 which is available on the website www.edmodo.com. Edmodo is a global education network that helps connect all students with others and the resources needed to reach their full potential (Ardana, Ariawan, \& Divayana, 2016). According to Witherspoon (2011) Edmodo is a safe social networking community that provides an educational micro blogging environment for teachers and learners, also it can be seen as a multi-platform Learning Management System (LMS) which can facilitate educators to set up and manage their online classes easily (Al-Said, 2015). Edmodo creates a safe environment for teachers and students in many areas of learning such as cooperation, feedback, etc., gives students freedom of time and place of learning, and helps control students and enables them to share their knowledge and ideas with features. the features in it. Edmodo allows teachers and students to communicate with each other through messages, thus providing participants with the opportunity to communicate and collaborate in a virtual classroom environment (Balasubramanian, Jaykumar, \& Fukey, 2014; Ekmekçi, 2016; Mokhtar, 2016).

Blended learning can affect not only cognitive aspects, but also affective aspects, one of which is mathematical disposition. Mathematical disposition is one of the factors that determines student learning success. Students need dispositions that will make them more persistent in facing more challenging problems, to be responsible for their own learning, and to develop good habits in mathematics. Mathematical learning basically adheres to: the principle of lifelong learning, the principle of active student learning, and the principle of "learning how to learn". The principle of active learning students, refers to the notion of learning as something done by students, and not something done to students.

According to Kilpatrick, Swafford, \& Findell (2002), mathematical disposition is the tendency to view mathematics as something that can be understood, feel mathematics as something useful, believe persevering and tenacious efforts in learning mathematics will produce results, perform actions as effective learners and the doer of mathematics itself. Polking argues that the disposition of mathematics shows: (1) confidence in using 
mathematics, solving problems, giving reasons and communicating ideas; 2) flexibility in investigating mathematical ideas and trying to find alternative methods for solving problems; (3) diligently working on mathematical tasks; (4) interest, curiosity (curiosity), and meeting ability in doing mathematical tasks; (5) tends to monitor, reflect on their own performance and reasoning; (6) assesses the application of mathematics to other situations in mathematics and daily experiences; (7) appreciation of the role of mathematics in culture and values, mathematics as a tool, and as a language (Hendriana \& Sumarmo, 2017). Based on the explanation of the mathematical disposition above, it can be concluded that the mathematical disposition is a strong tendency for students to be able to carry out various mathematical activities so as to solve mathematical problems effectively and efficiently.

A student may show a high mathematical disposition, but do not have enough knowledge or ability related to the substance of the material. However, if there are two students who have the same potential ability, but have different dispositions, it is believed that they will show different abilities. Students who have a high disposition will be more persistent, determined, and interested in exploring new things. This allows students to have more knowledge than students who do not exhibit such behavior. This knowledge causes students to have certain abilities. Thus it can be said that mathematical disposition supports mathematical abilities

A student's mathematical disposition is a key component to his or her success learning mathematics, and pre-service school teacher's mathematical disposition is integral to informing the mathematical disposition of their students (Feldhaus, 2014). Behavior, attitudes and awareness of teachers about students' mathematical dispositions are important factors that influence students' mathematical dispositions and to assess the effectiveness and quality of mathematics teachers (Kusmaryono, 2014). Dispositionis a trust or tendency that encourages a person to behave (response and action) (Incikabi, Tuna, \& Biber, 2013). What someone thinks will be actualized in action. The action will be good and done in a directed manner if the mental function is in good condition and controlled. Then, psychologically mathematical disposition will be closely related to mental function. Mathematical disposition is defined as a person's belief or behavior about mathematics that supports the tendency to observe mathematics as something that is logical, useful and valuable (Rahayu \& Kartono, 2014). The mathematical disposition indicators used in this study are: 1) self-confidence; 2) persistence and perseverance; 3) Think openly or flexibly; 4) Interest and Curiosity; and 5) Monitor and evaluate.

Based on the description above and from previous research, the purpose of this study was to obtain a description of students' mathematical disposition in blended learning using Edmodo during the COVID-19 pandemic.

\section{B. METHODS}

This type of research is qualitative research. Qualitative research is a research method used to explore and understand meaning (Creswell \& Creswell, 2018). The approach used in this research emphasizes descriptive studies for data analysis. The subjects in this study were four students from 6 th semester students majoring in mathematics education. The data in this study were collected directly by researchers, so researchers are the main instruments in this 
study. As revealed by Sugiyono (2016), researchers are the main instruments. The position of the researcher as the main instrument is as a planner, executor of data collection, analysis, interpretation of data and in the end the researcher becomes a reporter of research results (Moleong, 2019).

In addition to researchers as the main instrument, there are assistive instruments in the form of mathematical disposition questionnaires and field notes. The questionnaire given was a Likert scale questionnaire containing 25 negative and positive statements. The data collected is data about mathematical disposition related to indicators of mathematical disposition during the learning process. Mathematical disposition itself is attitudes that might arise in certain ways that students need to survive in facing problems, take responsibility in learning, and develop good work habits in mathematics. The results of students' mathematical disposition questionnaire scores were obtained based on the scoring criteria.

$$
\text { Final score }=\frac{\text { questionnaire score obtained }}{\text { maximum questionnaire score }} \times 100
$$

The final score on the disposition questionnaire obtained is then qualified with the following conditions in Table 1.

Table 1. Classification of Questionnaire Score Results

\begin{tabular}{cc}
\hline Questionnaire Score & Category \\
\hline $75-100$ & High \\
\hline $50-74,99$ & Moderate \\
\hline $25-49,99$ & Less \\
\hline $0-24,99$ & Low \\
\hline
\end{tabular}

\section{RESULT AND DISCUSSION}

This study discusses how students' mathematical disposition in learning blended learning uses Edmodo. In general, during the learning process, most students show indicators of selfconfidence and evaluate the work done in linear program subjects. The mathematical disposition of students is seen from the student questionnaire scores, where the questionnaire is given. The questionnaire given aims to find out the level of mathematical disposition of students after applying blended learning. To find out the level of students' mathematical disposition can be seen description of students' mathematical disposition data, where the mathematical disposition data can be seen in Table 2 below.

Table 2. Description of Students' Mathematical Disposition

\begin{tabular}{lcc}
\hline \multicolumn{1}{c}{ Indicator } & Questionnaire Score & Category \\
\hline Confidence & 74,52 & Moderate \\
\hline Persistence and Perseverance & 71,96 & Moderate \\
\hline Flexible & 74,36 & Moderate \\
\hline Interest and Curiosity & 66,35 & Moderate \\
\hline Monitoring and Evaluation & 82,45 & High \\
\hline
\end{tabular}

Based on Table 2 it is known that the indicators of student interest and curiosity are at the lowest score of 66.35. This happens because blended learning applied to a greater proportion of online learning due to the Covid-19 prevention decision starting from mid-March to the end of May. Students who initially have a curiosity because learning is combined between face to 
face and online learning tend to be bored because they cannot do face to face directly. During the Covid-19 pandemic the face-to-face system was virtually replaced by virtual face-to-face contact. This makes the students' lack of curiosity because they are blocked by several obstacles. Unlike the curiosity that is still relatively low even though it is in the medium category like the other three indicators namely confidence, persistence and perseverance, as well as open thinking, monitor and evaluate indicators are in the high category with a questionnaire score of 82.45. This is because students tend to have more time to evaluate the results of their work if learning uses blended learning.

For indicators of confidence will appear when the focus of learning on lecturers. This is because when learning lecturers ask many students who demand confidence in answering lecturer questions. The second indicator is persistence and perseverance. Students show this indicator the most. Because at every meeting the teacher always gives contextual problems related to students' daily lives that must be resolved by students, so students are persistent and persevering to solve the problems given by the teacher. While flexible indicators arise because students are given open ended questions in blended learning.

The mathematical disposition of students during blended learning is illustrated by S1, S2, S3 and S4. The mathematical disposition of the four students is described as follows. The first subject discussed is S1, always showing an indicator of mathematical disposition of confidence. S1 also shows a high indicator of curiosity. besides visible from his attitude to find out about material he did not know from the source book and ask questions about questions that he did not understand to the lecturer. Persistent and diligent indicators are also shown by $\mathrm{S} 1$, this is seen when S1 is always working on assignments given by lecturers. When the answer is wrong $\mathrm{S1}$ keep trying until he gets the right answer.

The second student discussed about mathematical disposition is S2. At the beginning of the S2 blended learning did not show indicators of mathematical disposition, not long after the S2 began to show indicators of mathematical disposition in terms of persistent and persistent in learning mathematics. This can be seen when lecturers give open ended questions, S2 immediately works on it with enthusiasm. S2 looks confident and has a curiosity and is persistent in working on mathematical problems. S2 seems to be really working on the questions given by lecturers both in class and at Edmodo, having curiosity. This can be seen from the attitude of S2 who often asks lecturers to clarify questions, or just ask whether the answers are correct or wrong.

The third subject, S3 from the beginning to the end of S3, does not show a mathematical disposition. When subject S3 is given the opportunity to go forward answering questions, the subject looks embarrassed to come forward to answer the questions given. This shows that S3's confidence is still not well developed. The fourth subject is S4. S4 does not display a mathematical disposition. The indicator of curiosity is not shown by $\mathrm{S} 4$ and sometimes it is busy with its own business so that it does not pay attention to the lecturer's explanation.

The first stage in blended learning is the face-to-face stage in the classroom. At this stage students are taught more linear program material using direct learning. The lecturer explained in front of the class then students were divided into groups to discuss related to the linear program. In face-to-face learning in class, students are given more open ended questions to develop flexible indicators or open thinking. The lecturer also poses a lot of questions to students, thus demanding students to be confident in answering lecturer questions.

The second stage in blended learning is online learning. In this online stage, the lecturer creates a virtual class at Edmodo and students are given a summary of learning material and videos that are relevant to the material discussed. In addition to listening to the learning materials and videos that have been given, students also look for material from various sources both from books and online sources such as emodules that are widely available on the 
internet. By using many learning resources, students can easily find the true meaning of the material discussed by drawing conclusions from several learning resources obtained. Thus students can understand the concepts of the material discussed properly. Another thing that is done in the online stage is discussion. The discussion in question is an online conversation conducted by students both with friends and with lecturers. In this discussion students are given the opportunity to express their opinions, convey their understanding related to the material discussed, ask questions about materials and issues that are not yet understood, and answer questions given by their friends or by lecturers. At this stage of discussion, if students experience errors in understanding a concept, then other students or lecturers can immediately improve the student's understanding by providing an explanation or correct understanding. Discussions conducted in online learning can be done by students whenever and wherever using their own computer or mobile devices. This online learning gives students unlimited time to study, they can access Edmodo discussion forums whenever and wherever they want as long as there is a computer or mobile device and a stable internet connection. Learning like this certainly will not make students feel bored in learning because they can learn when they feel like learning.

In addition to discussing the material, in online discussions students can also discuss problems or problems they get from books and from the internet. Problems that cannot be solved or discussion of questions that cannot be understood well are submitted by students then other students will respond to the problem. In this case students are trained to solve problems with the right procedures so that all students who participate in discussions understand well the meaning of the problem. Thus blended learning also trains students to work together and collaborate throughout the learning process. This certainly contributes positively to the sustainability of learning, where students who have high academic abilities are expected to be able to guide other students who have moderate and low academic abilities.

Learning done using the blended learning model creates learning that is able to attract students' interest in learning and can encourage students to be active in finding material and discussing with their friends. Through this learning students are led to actively find and understand knowledge by building their own knowledge. This is consistent with the learning theory that underlies the learning model of blended learning, namely the theory of learning constructivism (individual learning). Individual learning in this theory is active students, who can build their own knowledge, subjectively, dynamically and developing. Then process and understand information, so students are able to master the learning material independently. Thus the blended learning model can be used as a model to improve students' mathematical disposition. If the mathematical disposition is high then student achievement is high. This is consistent with research conducted by Lin \& ChunTai (2016) which states that there is a relationship between student disposition and mathematical achievement. The results show that mathematics educators need to focus not only on developing mathematical knowledge and skills, but on developing mathematical dispositions. In addition, research conducted by Y. W. Lin, Tseng, \& Chiang (2017) states that shows that blended learning in experimental groups has a positive effect not only on learning outcomes, but also on their attitudes towards learning mathematics. While research Mulenga \& Marbán (2020) states digital learning in mathematics allows students to learn comfortably in their homes. As long as students have the necessary digital devices, access to the internet, affordable internet costs and adequate electricity supply, they can be obtained front seat in virtual mathematics classes.

\section{CONCLUSION AND SUGGESTIONS}

Based on the results of research and discussion concluded that the average level of mathematical disposition of students is classified as moderate. If seen from the indicators, only the monitor and evaluate indicators are classified as high category. Indicators of 
persistence and perseverance, especially when lecturers present interesting contextual problems. Many indicators of curiosity arise when lecturers invite students to be active in learning, for example students are invited to study in groups. Many self-confidence indicators appear when lecturers ask students questions. While many flexible indicators appear when lecturers give open ended questions.

Based on the findings obtained in this study, the following suggestions can be made. First, other researchers are advised to try out these mathematical dispositions on different learning models. Second, in further research it is suggested to try out the blended learning model both in cognitive and affective aspects besides mathematical disposition.

\section{ACKNOWLEDGEMENT}

This study is inseparable from the help and support of many parties to thanks the Mathematics Education Study Program of FKIP UMT, LPPM University of Muhammadiyah Tangerang, BRIN Ministry of Research and Technology RI who has funded this research and all those who can not mention one by one.

\section{REFERENCES}

Agnoletto, R., \& Queiroz, V. C. (2020). COVID-19 and The Challenges in Education. CEST Bulliton, 5(2), $1-2$.

Al-Said, K. M. (2015). Students' Perceptions of Edmodo and Mobile Learning and Their Real Barriers Towards Them. Turkish Online Journal of Educational Technology, 14(2), 167-180.

Ardana, I. M., Ariawan, I. P., \& Divayana, D. G. (2016). Development of Decision Support System to Selection of the Blended Learning Platforms for Mathematics and ICT Learning at SMK TI Udayana. International Journal of Advanced Research in Artificial Intelligence, 5(12), 15-18. https://doi.org/10.14569/ijarai.2016.051203

Balasubramanian, K., Jaykumar, V., \& Fukey, L. N. (2014). A Study on "Student Preference towards the Use of Edmodo as a Learning Platform to Create Responsible Learning Environment." Procedia Social and Behavioral Sciences, 144, 416-422. https://doi.org/10.1016/j.sbspro.2014.07.311

Çakır, H., \& Bichelmeyer, B. A. (2016). Effects of Teacher Professional Characteristics on Student Achievement: An Investigation in Blended Learning Environment with Standards-Based Curriculum. Interactive Learning Environments, 24(1), 20-32. https://doi.org/10.1080/10494820.2013.817437

Castro, R. (2019). Blended Learning in Higher Education: Trends and Capabilities. Education and Information Technologies, 24(4), 2523-2546. https://doi.org/10.1007/s10639-019-09886-3

Creswell, J. W., \& Creswell, J. D. (2018). Research and Design Qualitative, Quantitative and Mixed Methods Approaches. In Thousand Oaks California.

Dempsey, M., \& Burke, J. (2020). COVID-19 Practice in Primary Schools in Ireland Report: A Two-month Follow-up. https://doi.org/10.13140/RG.2.2.14091.03369

Ekmekçi, E. (2016). Integrating Edmodo into Foreign Language Classes as an Assessment Tool. Participatory Educational Research, Special Is, 1-11. https://doi.org/10.17275/per.16.spi.1.1

Eryilmaz, M. (2015). The Effectiveness Of Blended Learning Environments. Contemporary Issues in Education Research (CIER), 8(4), 251-256. https://doi.org/10.19030/cier.v8i4.9433

Feldhaus, C. (2014). How Pre Service Elementary School Teachers' Mathematical Dispositions are Influenced by School Mathematics. American International Journal of Contemporary Research, 4(6), 91-97. Retrieved from http://www.aijcrnet.com/journals/Vol_4_No_6_June_2014/11.pdf

Hendriana, H., \& Sumarmo, U. (2017). Penilaian Pembelajaran Matematika. In PT Refika Aditama.

Hong, J. C., Hwang, M. Y., Tai, K. H., \& Kuo, Y. C. (2016). Parental Monitoring Predicts Students' Prosocial and Impulsive Tendencies Relevant to Consequence-Based Reasoning in a Blended Learning Environment. Interactive Learning Environments, 24(7), 1534-1551. https://doi.org/10.1080/10494820.2015.1041397

Horn, M. B., \& Staker, H. (2014). Blended: Using Disruptive Innovation to Improve Schools. In Blended: 
using disruptive innovation to improve schools. San Francisco: Jossey-Bass.

Incikabi, L., Tuna, A., \& Biber, A. C. (2013). An Analysis Of Mathematics Teacher Candidates Critical Thinking Dispositions And Their Logical Thinking Skills. Journal of International Education Research (JIER), 4(2), 2141-2161. https://doi.org/10.19030/jier.v9i3.7884

Jou, M., Lin, Y. T., \& Wu, D. W. (2016). Effect of a Blended Learning Environment on Student Critical Thinking and Knowledge Transformation. Interactive Learning Environments, 24(6), 1131-1147. https://doi.org/10.1080/10494820.2014.961485

Kilpatrick, J., Swafford, J., \& Findell, B. (2002). Adding It Up: Helping Children Learn Mathematics. In Book Reviews. https://doi.org/https://doi.org/10.17226/9822.

Kusmaryono, I. (2014). The Importance of Mathematical Power in Mathematics Learning. International Conference on Mathematics, Sciense, and Education (ICMSE), 35-40.

Lin, S.-W., \& ChunTai, W. (2016). A Longitudinal Study for Types and Changes of Students' Mathematical Disposition. Universal Journal of Educational Research, 4(8), 1903-1911. https://doi.org/10.13189/ujer.2016.040821

Lin, Y. W., Tseng, C. L., \& Chiang, P. J. (2017). The Effect of Blended Learning in Mathematics Course. Eurasia Journal of Mathematics, Science and Technology Education, 13(3), 741-770. https://doi.org/10.12973/eurasia.2017.00641a

Mokhtar, F. A. (2016). Rethinking Conventional Teaching In Language Learning And Proposing Edmodo As Intervention: A Qualitative Analysis. Malaysian Online Journal of Educational Technology, 4(2), 22-37.

Moleong, L. J. (2019). Metodologi Penelitian Kualitatif (Edisi Revisi). PT. Remaja Rosda Karya. https://doi.org/10.1016/j.carbpol.2013.02.055

Mulenga, E. M., \& Marbán, J. M. (2020). Is COVID-19 the Gateway for Digital Learning in Mathematics Education? Contemporary Educational Technology, 12(2), 1-11. https://doi.org/10.30935/cedtech/7949

Quevedo, A. (2011). Blended-Learning Implementation in Undergraduate Teacher's Formation Courses: Difficulties from The Students' Point of View. International Journal of Technology, Knowledge and Society, 7(2), 187-200. https://doi.org/10.18848/18323669/CGP/v07i02/56192

Rahayu, R., \& Kartono. (2014). The Effect of Mathematical Disposition toward Problem Solving Ability Based On IDEAL Problem Solver. International Journal of Science and Research, 3(10), 2012-2015.

Smith, J. G., \& Suzuki, S. (2015). Embedded Blended Learning within an Algebra Classroom: A Multimedia Capture Experiment. Journal of Computer Assisted Learning, 31(2), 133-147. https://doi.org/10.1111/jcal.12083

Sugiyono. (2016). Metode Penelitian Pendidikan (Pendekatan Kuantitatif, Penelitian Kualitatif, dan R\&D). In Alfabeta. Bandung: Alfabeta.

Van Niekerk, J., \& Webb, P. (2016). The Effectiveness of Brain-Compatible Blended Learning Material in the Teaching of Programming Logic. Computers and Education, 103, 16-27. https://doi.org/10.1016/j.compedu.2016.09.008

Watson, J., \& Murin, A. (2014). A History of K-12 Online and Blended Instruction in The United States. In Handbook of Research on K-12 Online and Blended Learning. ETC Press Pub. 